\title{
Sadfishing Phenomenon of \#Justiceforaudrey (Hashtag) On Twitter
}

\author{
${ }^{1}$ Citra Eka Putri, ${ }^{2}$ Novita Damayanti, ${ }^{3}$ Radja Erland Hamzah \\ ${ }^{1,2,3}$ Faculty of Communication, University of Prof. Dr. Moestopo (Beragama) \\ Jl. Hang Lekir I No. 8, Jakarta, Indonesia. \\ E-mail: 1'ekaputricitra8@gmail.com, ${ }^{2}$ novitadi@yahoo.com, ${ }^{3}$ radjaerland@gmail.com
}

\begin{abstract}
People use social media as a means to share everything about themselves and their daily lives. Many users tell stories or things they see that can attract the attention and sympathy of many people in social media. One of the cases that went viral at the beginning of 2019 was a case of alleged violence that had befallen 17-years old Pontianak SMPN (junior high school) student named Audrey who claimed to have been persecuted by several high school students. The Audrey case drew attention of many circles and was viral through the hashtag JusticeForAudrey on Twitter social media in April 2019. The hashtag had even occupied the world trending. The viral hashtag 'JusticeForAudrey' and the reaction of a number of public figures to this case made many people sympathetic and gave support to Audrey. Through the power of social media, this case was widespread and reached various groups in cyberspace. The issue of humanity is indeed an issue that is able to bring sympathy from everyone, but this can immediately change and turn around against the victim when unexpected new evidence \& findings are revealed. This study aims to analyze the phenomenon of sadfishing (provoking sadness) from a teenager named Audrey who intentionally uploaded and portrayed her sadness on social media to be viral and brought a lot of public attention. This research uses a qualitative method with a case study approach. The theory applied in this study is related to the use of social media, namely media system dependency theory (MSD) or media dependency.
\end{abstract}

Keywords: Sadfishing, Media social, Viral, \#JusticeForAudrey

\section{INTRODUCTION}

Social media has changed the world a lot, turning around many thoughts and theories; the level of communication merges in one platform which we now call social media or social networking (Watie, 2011). A social media user can easily access anything only by connecting to the internet, even if the access is slow. Users do not need to spend a lot of money, do not need expensive tools, and it can be done alone. Social media users can freely edit, add, and modify text, images, videos, graphics, and various other content models to eventually share them on social networks. Social networks now provide direct feedback for users in the form of likes, comments, and shares. This encourages many social media users to do intrigues and tricks in order to get likes, shares, and comments as many as possible as a form of manifestation of self-attention and existence.

A new phenomenon trending on social media/cyberspace is sadfishing which interpreted as provoking sadness. Sadfishing describe the behavior of someone who makes excessive statements about their emotional problems to gain sympathy from many people on social media. Unwittingly, this sadfishing phenomenon is common among teenagers everywhere in the world; they want to get a lot of attention from others and their stories become viral. They do not hesitate to share their personal status on social media to get lots of likes, shares, and comments so that others sympathize with 
them; they even become oblivious to the limitations of their privacy. Everything that they pour out on social media is actually consumed by many people; some people end up feeling compassionate and pity and giving their support, but some who do not understand will see it as excessive sadfishing actions. These people probably send many negative comments which can be considered as cyberbullying, so that people who do sadfishing will get more depressed and psychologically worst.

The sadfishing case in this study is the (hashtag) \#justiceforaudrey that had become trending on social media Twitter in April 2019. Started from taunting with her friends on social media, Audrey then agreed to meet them somewhere, but unfortunately she became a victim of beating by herfriends. Audrey's parents then reported the beating incident to Pontianak Police. After the report, Audrey uploaded a lot of her heartfelt content on her Instagram account @niggaaareyy before it was finally being talked about on Twitter by@syarifahmelinda account. According to Audrey's confession, she was beaten up by a number of high school students. She even claimed that her reproductive organ was injured. Social media users then have great sympathy for Audrey-beating-case on Twitter and even the hashtag \#JusticeForAudrey has become trending on Twitter and on several Indonesian news portals such as liputan6.com and tribunnews.com, including mainstream media of television and radio.

There was also a petition as the form of support for that 14-year-old girl. Audrey was invited to many television programs to talk about the incident. Support and help came from many parties including public figures as anti-bullying support for children in Indonesia. However, contradicted to Audrey's confession, after the police conducted an investigation, the results of visum et repertum showed there were no bruises on Audrey's body, especially on the 'vital' organs as reported in Twitter. In line with the police report, the perpetrators who at that time had apologized in front of the media also claimed they did not hurt Audrey's vital organs. Netizens finally turned around accusing Audrey of spreading hoax news and enlivening \#Audreyjugabersalah (Audrey was also guilty) hashtag on Twitter. This incident is interesting because it relates to the phenomenon of sadfishing by young people in cyberspace, one of which is the case of Audrey with the hashtag \#Justiceforaudrey on Twitter.

Research conducted by Primada Qurrota Ayun discusses the phenomenon of teenagers using social media in forming their self-identity (Ayun, 2015). The research explains that the phenomenon of Indonesian teenagers in using social media is quite interesting to study. Many teenagers build their identities to get the image they want and express their personal problems on social media.

Fanny Hendro Aryo Putro in his research entitled Perilaku Penggunaan Media Sosial dan Identitas Diri (Social Media Usage Behavior and Self Identity) (Putro, 2017) found that social media can be interpreted as a modern interface that connect individuals everywhere in the world. Although social networking has a few positive influences on individual's behavior, it is crucial to remember that social networking has more negative influences where a person can behave 'beyond' the limits of normal people. For example, people tend to showing off in their social networks about their trips to many countries abroad, the high speed of speedometer they have, their food, etc. which can cause "dehumanization" where someone is more engaged with cyberspace than the real environment around him/her.

Distortion in the function of social 
media has formed many new phenomena of cyber cultures. This study aims to analyze the phenomenon of sadfishing (provoking sadness) from a teenager namedAudrey who intentionally uploaded her sadness on Twitter to become viral and bring a lot of public attention through justiceforaudrey hashtag. This research uses a qualitative approach with a case study method, in which the researchers want to explore what information can be learned or taken from the case. One important thing to consider in selecting a case is that the researchers believe they can get further and in-depth scientific knowledge from that case, where the phenomenon of sadfishing (provoking sadness) is a new phenomenon on social media. A case study can also be said as an Instrumental Case Study, where a case study used to fulfill the personal interests of researchers in a particular problem but not building a particular theory. The theory used in this study is related to the use of social media, namely the theory of media system dependency.

\section{METHOD}

Initially, qualitative research developed in the field research. But in the end, according to Tracy, qualitative research is increasingly being used to study a virtual context and mediation (Tracy, 2013). Referring to Tracy's view, the research on the phenomenon of sadfishing on social media is qualitative research with a virtual context.

Constructivism is a paradigm used in this study; and as we all know, constructivist is almost an antithesis of understanding that put the importance of observation and objectivity in finding a reality of science (Salim, 2006).

This study aims to analyze the phenomenon of sadfishing on social media, especially in the case of (hashtag) \#justiceforaudrey. This research uses a qualitative approach with a case study method. This study is designed as a case study that has dynamic characteristics to obtain an overview of various interesting issues in social life (Pawito, 2007). A case study can also be interpreted as "a comprehensive description and explanation of various aspects of an individual, a group, an organization (community), a program, or a social situation" (Mulyana, 2008). In a case study, the researcher wants to explore what information can be learned or what conclusion can be drawn from a case, either single or plural cases. As mentioned above, one of the important considerations in selecting a case is the belief of the researcher that he/she will gain further and in-depth scientific knowledge; and the phenomenon of sadfishing is a new phenomenon on social media.

In line with the needs, the data collection technique in this study use the steps commonly used in the descriptive case study method and are explained as follows. First, the researcher must be sure that the theme, case, or topic chosen is an area that he/she masters and is interested in. Second, researchers must collect as much literature or reading material as possible, whether in the form of journals, scientific magazines, previous research results, books, magazines, or newspapers related to the case. According to Yin (1994), reading the literature is very important to broaden the insight of researchers in the field studied and sharpen the formulation of the problem proposed. Third is to formulate research focus and problems. Research focus is crucial for the researcher to concentrate on one point as the center of attention. Fourth is collecting research data. In the case study method, data can be obtained through several techniques such as interviews, participant observation, and documentation. As a key instrument, researchers can measure the accuracy and adequacy of data; determine the right 
informant to be interviewed as well as when and where the interviews will be conducted. For this study, the researchers interviewed an expert and observer of social media and child psychologist. Fifth is improving the data. The data that has been collected needs to be refined; data is said to be perfect if it is able to answer the research problem statement. Sixth is data processing and analysis. In this stage, important information will be obtained in the form of research findings where the ability to analyze data is largely determined by the broadness of theoretical insight of researchers in the field under study, particularly related to communication and social media studies on the phenomenon of sadfishing on the \#justiceforaudrey hashtag on Twitter. Lastly, the data has been collected and analyzed is arranged logically and systematically so that the researcher can see and examine the important components in the data presentation for verification and conclusions. At this stage, the researcher interprets data in accordance with the context of the problem and the purpose of the study to finally draw a conclusion.

\section{RESULTS AND DISCUSSION Sadfishing Phenomenon on Social Media}

Social phenomena are symptoms or events that occur and can be observed in social life. Social phenomena are also called social symptom. The point is that social phenomena or social symptom are influenced by forms of social change. The term sadfishing allegedly emerged from the post descriptions by celebrities such as Justin Bieber and Kendall Jenner. Both expressed openly about the pressure of being a public figure since a very young age. This is considered a new trend for young people that later be adopted and brought into their social media (Abraham, 2019). Initialized from the term, the phenomenon of sadfishing has now become a new trend among young people and there are even adults who also do sadfishing on social media. Sadfishing is actually different from sharing emotional /personal problem or experiences on social media; sadfishing here emphasizes the desire of someone to get a lot of attention since they think their problems can attract people's attention.

Social media invites anyone who is interested in certain content to participate by giving feedback in the form of likes, shares, or comments. Usually, the information provided is spread so quickly in cyberspace (Putri, Nurwati, \& Budiarti, 2016). Teenagers frequently use social media as a medium to show off: showing off their partners, friends, clothes, beauty products, bodies, including sadness. Apparently, the trend of showing off sadness or referred to as "sadfishing" is a term used to describe the act of making exaggerated statements about one's emotional problems to gain sympathy. It can also say that sadfishing is a way for someone to express their vulnerability and psychological condition through social media.

The term sadfishing is commonly used to refer to the emotional posts expressed by people, especially teenagers, who seek support by discussing issues around anxiety and depression on social media. By sharing their stories or sharing their sad feelings on social media, they hope they can share the same sadness and depression. But, actually, it can also bring negative comments on social media. Sadfishing is considered toxic, harmful, and causes panic to parents. When sadfishing becomes a trend among world celebrities and young people follow it, then it becomes a big disaster. By sharing emotional problems on social media, young people actually become miserable and get more depressed (Jargon, 2019).

The results of Audrey's case 
research on social media proved that in the end, Audrey admitted she was guilty of intentionally spreading her sad story on social media. She did it to get a lot of attention and support in the form of empathy and sympathy from many people so that the news went viral. Many netizens are provoked by the news; even the YouTubers, celebrities, government, and media were clamorously commenting and spreading the hashtag of justice for Audrey solely to support her in dealing with harassment issues. A thing which triggered this news to go viral was that Audrey claimed she had also been sexually assaulted. But the truth was not proven because after the police arrested the beatings and made a report on Audrey case, they announced that there was no evidence of violence, bruises, and blunt force clashes on Audrey's vital area as she had said earlier on social media. Many netizens have finally realized that they were instigated by Audrey's tweets without checking out the truth first and then they believed Audrey was lying. This case can be called a Sadfishing phenomenon on social media. As it is explained before, the phenomenon of Sadfishing is mostly done by young people because they want to get famous fast and get a lot of attention. They use social media because it can easily spread any news to many people, not to mention that now Indonesia is the third largest country in the use of social media. Social media is also believed to be the fastest in responding compared to any other media.

\section{DISCUSSION}

\section{Media System Dependency}

Media system dependency theory was developed by Sandra Ball Rokeach and Melvin Defleur in 1976 (BallRokeach, 2010). This theory is based on classical sociology literature where the media and its users must be studied in the context of a larger social system
(Ognyanova \& Ball-Rokeach, 2015). This media system dependency binds a reciprocal relationship among broad social systems, mass media, and the individual in an exhaustive explanation of media effects. Essentially, the basic hypothesis of dependency states that the more a person depends on the media to fulfill his/her needs, the more important the media will be in his/her life; in another word, the impact of the media will be even greater on human life.

Social media as part of new media has given a new insight that power does works in all aspects of human life, including in virtual space (Jatmiko, 2019). Social media has changed the world a lot with considerable thoughts and theories. All levels of communication merged in one medium called social networking/ social media. Since social media increasingly opens up opportunities for each individual involved in it to freely express their opinions, the consequences emerged should also be on alert. To keep this freedom on the right track and does not violate any restriction, each user must have self-control (Watie, 2011). The theory of media dependence can also be said as the state of users who consider the media as part of their most important life needs. Many cases arise when people no longer hesitate to admit that they have a dependency on social media. (Ognyanova \& Ball-Rokeach, 2015).

This distortionin the function of social media is an obstacle in daily life that forms new phenomena. Now many social media users actually feel more comfortable pouring out their sadness or misery on social media rather than solving the problems in real life. They desperate for people's attention and seek for justification in cyberspace as in the case of \#justiceforaudrey in April 2019 which was widely discussed on Twitter. Audrey considers herself a victim of beatings of high school girls in Pontianak. Initially, 
she posted her experience on Instagram using@niggaaareyy account before she was finally being talked about on Twitter by@ syarifahmelinda account. Syarifah in her tweets revealed the violence perpetrated by Audrey's friends. In addition to getting bruises all over her body, Audrey also claimed to have been verbally and sexually abused. Audey's confession then became the world's attention where many people talked about it, be it the government, public figures, and media. They supported her to fight violence against children. Many public figures also gave their statements about this matter. In fact, many social media users spread this news to many social media platforms such as liputan6.com and tribunnews.com, and that was how the news became viral and number one trending on Twitter.

\section{\#justiceforaudrey Went Viral}

The concept of virality came out at the beginning of the internet and developed rapidly in the era of social media. Social media is a technology with the ability to directly share the content with many people at the same time and in a way they want, where people use the internet and social media to communicate with each other (Staiou \& Giannakoulopoulos, 2018).

The word viral means spreading quickly. Viral is a term usually used in cyberspace to describe the rapid spread of news or information. Viral can be defined as network news spread online mostly through social media that is faster and wider than other news (Al-Rawi, 2019). This viral concept originated from a metaphorical reference for biology and the nature of the spread of viruses and microbes. However, modern social research aims to build more comprehensive and complex approaches to explain the complexity of social phenomena (Pöyry, Laaksonen,
Kekkonen, \& Pääkkönen, 2018).

Social media has a very big role in turning the news into viral. Social media is considered as a supporting medium in the context of spreading messages. The case of save Audrey hashtag was first revealed by Twitter user of @syarifahmelinda account in April 2019. In a tweet series (Justice for Audrey), the account narrated that Audrey is a 14-year student who was beaten and persecuted by 12 high school students in Pontianak on 29 March 2019. Initially, the problem was triggered by the quarrel between Audrey and her friends on WhatsApp related to the love affair of one of the perpetrators who has D.A. initials. D.A. is known to be the girlfriend of Audrey's sister's ex-boyfriend. After the quarrel on WA, the persecution happened. Audrey claimed through twitter account@ Syarifahmelinda that the perpetrators hit her head hard on the street, kicked her stomach many times, throttled her, and flushed her with water in turn. Not only that, Audrey's face was also kicked by mountain sandals and made her nose bleed, bruises, head bumps, and other internal injuries. Worse yet, Audrey also admitted that there was one of the perpetrators who tried to sexually assault her. This case soon became viral after the @syarifahmelinda account tweeted Audrey's story on Twitter. Citizens/netizens were angry with the perpetrators of female students from various high schools in Pontianak. The hashtag \#JusticeForAudrey became a global trending topic. Almost all netizens condemned the perpetrators' rude actions to the victim and support Audrey.

While the case was getting viral, new facts began to emerge. In contrast to Audrey's confession, the police revealed the results of the visum et repertum showing that there were no bruises on Audrey's body, especially in her genital as reported previously. In line with the police, the perpetrators who at that time 
had apologized in front of the media also claimed they did not hurt Audrey's vital organ. Netizens then turned around accusing Audrey of spreading hoax and enlivening hashtag\#Audrey jugabersalah (Audrey is also gulity) on social media (Tribunjakarta.com, 2019). Audrey is said to be one of the teenagers who do sadfishing on social media because she gained a lot of sympathy and compassion from many people when she poured out her problem of violence on social media. The truth about the Audrey case has not yet been verified, but social networks had already spread the news like a virus outbreak spreading so quickly through time and space and became viral in cyberspace.

Nowadays, it is undeniable that social media can be used as an effective tool to spread news or information. The Audrey case got a lot of attention from many people because it was uploaded through social media, considering the spectrum of news spread in cyberspace is very broad and develop very quickly that even can reach the whole world without having space and time (spatial) limitations. In the internet as an online media, news/information that has not even verified yet (whether is it true or not) can spread quickly. In just seconds, a news can be directly spread and accessed by users through social media (Hidaya, Qalby, Alaydrus, Darmayanti, \& Salsabila, 2019).

\section{Sympathy and Empathy in the Era of Social Media}

People will do anything to get the attention of others on social media. Social media is capable of removing the limitations in socializing because it has no space and time restrictions. Social media users can communicate wherever and whenever they want. Social media has a huge influence on one's life, especially for teenagers since there is no single day passed by without social media (Cahyono, 2016).

Nowadays, social media platforms are proliferated. All of them offer the convenience of sharing everything both information and news to your friends and other fellow users who are not even known. Many people use social media as a medium to confide in his personal problems in order to get a lot of sympathy and attention from other people who read it. Moreover, social media is also provide direct feedback to users in the form of likes, shares, or comments that binds people to participate in life and problems experienced by others.

Empathy plays an important role in teenagers' social functions and is often regarded as a "social glue" in peer interaction in one's childhood (BaronCohen \& Wheelwright, 2004). Empathy largely develops through experience within social interactions. According to the Perception Action Model (PAM), empathy is a form of emotion in the cognitive component related to the understanding and recognition of others (Preston \& Hofelich, 2012). Although the affective and cognitive components are closely related to each other, they are different and do not always occur together (Nummenmaa, Hirvonen, Parkkola, \& Hietanen, 2008).

The use of social media can influence one's empathy and it is important to assess which aspects of empathy involve within. Interaction on social media is valued as a way to understand others and people will expect feedback in the form of positive empathy (Vossen \& Valkenburg, 2016). The cyberspace is considered a collection of entities that have social potential to broadly educate one's humanity side. The reason why the Audrey case got a lot of attention and sympathy is because humanitarian cases on social media play a major role in mobilizing support for sympathy and 
empathy among people, especially if it is related to violence against children. There are many media in Indonesia publish news of violence against children either at school or on social media which draws a lot of sympathy and compassion from many people.

\section{CONCLUSION}

The sadfishing phenomenon is widely used to refer to emotional post of someone (usually sadness post), especially from teenagers who seek support by sharing their anxiety and depression on social media. The effect of media in theory of media system dependency is that the more a person depends on the media to fulfill his/her needs, the media will become crucial in his/herlife; therefore, the impact of the media will be greater in human life. They consider cyberspace as a way out for every problem occurs in the real world, so that many social media users fail distinguish lies in the cyberspace and in the real world. The viral of Audrey case has brought a lot of support for the problem of cyberbullying in Indonesia and has come to the attention of many parties, especially the government which dilligently socilalize the stop bullying movement. Online world is still regarded by many as a collection of social entities that have the potential to educate one's humanity. This is the reason why the Audrey case gained a lot of sympathy because humanitarian cases on social media has an important role in drawing sympathy and empathy from people. But apparently, the viral news about the abuse of Audrey is not yet clear. Many netizens and public figures rush to react to this problem without checking the truth first. As the case became more viral, new facts emerged which were against Audrey's confession. The police revealed the report which showed that there were no bruises on Audrey's body, moreover in the 'vital' organ as previously reported. In line with the police, the perpetrators who at that time had apologized in front of the media also claimed they did not hurt Audrey's vital organ. Netizens then turned around accusing Audrey of spreading hoax and enlivening hashtag \#Audreyjugasalah on Twitter. This proves that internet is an online media that capable of spreading the information quickly, regardless whether it is true or not. In just seconds, an event can immediately spread and easily accessed by other internet users. It is coupled with the phenomenon of sadfishing which increasingly rampant and unconsciously done by teenagers in Indonesia. They think that social media is a medium for uploading personal issues that can draw compassion and sympathy from many people with the hope that the problem will go viral.

\section{REFERENCES}

Abraham, A. (2019). Kendall Jenner and Instagram influencers are being blamed for a so-called new phenomenon and trend. Retrieved November 21, 2019, from https:// www.dazeddigital.com/life-culture/ article/46280/1/sadfishing-youngpeople-online-kendall-jenner-takeseriously

Al-Rawi, A. (2019). Viral News on Social Media. Digital Journalism, 7(1), 6379. https://doi.org/10.1080/2167081 1.2017.1387062

Ayun, P. Q. (2015). Fenomena Remaja Menggunakan Media Sosial dalam Membentuk Identitas. Channel, 3(2), 1-16. https://doi.org/10.24090/ komunika.v11i2.1365

Ball-Rokeach, S. J. (2010). Media System Dependency Theory. In The International Encyclopedia of Communication. https://doi. org/10.1002/9781405186407. wbiecm051

Baron-Cohen, S., \& Wheelwright, S. (2004). The empathy quotient: An investigation of adults with asperger syndrome or high functioning autism, and normal sex 
differences. Journal of Autism and Developmental Disorders, 34(2), 163-175. https://doi.org/10.1023/ B:JADD.0000022607.19833.00

Cahyono, A. S. (2016). Pengaruh Sosial Media Terhadap Perubahan Sosial Masyarakat di Indonesia. Publiciana, 9(1), 140-157.

Hidaya, N., Qalby, N., Alaydrus, S. S., Darmayanti, A., \& Salsabila, A. P. (2019). Pengaruh Media Sosial Terhadap Penyebaran Hoax Oleh Digital Native. Retrieved January 23, 2020, from https://www. researchgate.net/profile/Nurul Hidayaa/publication/330135181 P E N G A R U H M E D I A S O S I A L T E R H A D A P PEN Y EB A R A N H AX OLEH_DIGITAL_NATIVE/ links/5c2 2 f44a1 a6fdcc $\bar{d} 6$ b59089d3/ PENGARUH-MEDIA-SOSIALTERHADAP-PENYEBARANHOAX-OLEH-DIGITAL-NATIVE. pdf

Jargon, J. (2019). Sadfishing, Predators and Bullies: The Hazards of Being 'Real' on Social Media. Retrieved November 20, 2019, from https://www.wsj.com/articles/ sadfishing-predators-and-bulliesthe-hazards-of-being-real-on-socialmedia-11573554603

Jatmiko, M. I. (2019). Post-Truth, Media Sosial, Dan Misinformasi:Pergolakan Wacana Politik Pemilihan Presiden Indonesia Tahun 2019. Jurnal Dakwah Tabligh, 20(1), 21. https:// doi.org/10.24252/jdt.v20i1.9529

Mulyana, D. (2008). Qualitative Research Methodology: New Paradigms of Communication and Other Social Sciences. (Metodologi Penelitian Kualitatif: Paradigma Baru Ilmu Komunikasi dan Ilmu Sosial Lainnya). Bandung: Remaja Rosdakarya.

Nummenmaa, L., Hirvonen, J., Parkkola, R., \& Hietanen, J. K. (2008). Is emotional contagion special? An fMRI study on neural systems for affective and cognitive empathy. Neuroimage, 43, 571-580. https://doi.org/10.1016/j. neuroimage.2008.08.014

Ognyanova, K., \& Ball-Rokeach, S. J. (2015). Political Efficacy on the Internet: A Media System Dependency Approach. In L. Robinson, S. R. Cotten, \& J. Schulz (Eds.), Communication and Information Technologies Annual: Politics, Participation, and Production (pp. 3-27). Emerald Group Publishing. https://doi.org/10.1108/s2050206020150000009001

Pawito. (2007). Penelitian Komunikasi Kualitatif. Yogyakarta: LKIS Pelangi Aksara.

Pöyry, E., Laaksonen, S.-M., Kekkonen, A., \& Pääkkönen, J. (2018). Anatomy of Viral Social Media Events. In Proceedings of the 51st Hawaii International Conference on System Sciences (Vol. 9). https://doi. org/10.24251/hicss.2018.272

Preston, S. D., \& Hofelich, A. J. (2012). The Many Faces of Empathy: Parsing Empathic Phenomena through a Proximate, Dynamic-Systems View of Representing the Other in the Self. International Society For Research on Emotion, 4(1), 24-33. https://doi.org/https://doi. org/10.1177/1754073911421378

Putri, W. S. R., Nurwati, N., \& Budiarti, M. (2016). Pengaruh Media Sosial Terhadap Perilaku Remaja. In Prosiding Penelitian dan Pengabdian kepada Masyarakat (Vol. 3, pp. 4751). https://doi.org/10.24198/jppm. v3i1.13625

Putro, F. H. A. (2017). Perilaku Penggunaan Media Sosial dan Identitas Diri (Studi Deskriptif Kualitatif Tentang Perilaku Penggunaan Media Sosial dan Identitas Diri di Kalangan Mahasiswa S1 Jurusan Komunikasi Universitas Slamet Riyadi Surakarta). Transformasi, 2(32), 147-155. Retrieved from http://ejurnal.unisri.ac.id/index.php/ Transformasi/article/view/1805

Salim, A. (2006). Theory and Paradigm: Social Research. (Teori dan Paradigma: Penelitian Sosial). Yogyakarta: Tiara Wacana. 
Citra Eka Putri, dkk. Sadfishing Phenomenon of \#Justiceforaudrey...

Staiou, E., \& Giannakoulopoulos, A. (2018). A Case Study on Viral Journalism in Greece: The Figures, The Trends And The Factors of Success. Journal of Media Critiques (JMC), 4(14), 323-332. https://doi.org/10.17349/ jmc118225

Tracy, S. J. (2013). Qualitative research methods: collecting evidence, crafting analysis, communicating impact. West Sussex: WileyBlackwell.

Tribunjakarta.com. (2019). 3 Terdakwa Divonis Bersalah, Audrey Unggah Curhatan di Media Sosial Soal Kasus Penganiayaannya Artikel ini telah tayang di Tribunjakarta.com dengan judul 3 Terdakwa Divonis Bersalah, Audrey Unggah Curhatan di Media Sosial Soal Kasus Penganiayaannya, https. Retrieved November 28, 2019, from https://jakarta.tribunnews. com/2019/09/05/3-terdakwadivonis-bersalah-audrey-unggahcurhatan-di-media-sosial-soal-kasuspenganiayaannya

Vossen, H. G. M., \& Valkenburg, P. M. (2016). Do social media foster or curtail adolescents' empathy? A longitudinal study. Computers in Human Behavior, 63, 118-124. https://doi. org/10.1016/j.chb.2016.05.040

Watie, E. D. S. (2011). Komunikasi dan Media Sosial (Communications and Social Media). Jurnal The Messenger, 3(1), 69-75. https://doi.org/10.26623/ themessenger.v $3 \mathrm{i} 2.270$

We are social. (2019). Indonesia Digital 2019. Retrieved November 22, 2019, from https://websindo.com/ indonesia-digital-2019-tinjauanumum/\%0Ahttps://datareportal.com/ reports/digital-2019-indonesia 